\title{
Laser Phototherapy as a Treatment for Radiotherapy-Induced Oral Mucositis
}

\author{
Maíra Dória Martinez da Costa LINO1 \\ Fabíola Bastos de CARVALHO ${ }^{1}$ \\ Lara Ramalho de OLIVEIRA ${ }^{2}$ \\ Edval Barreto MAGALHÃES ${ }^{1}$ \\ Antônio Luiz Barbosa PINHEIRO ${ }^{1}$ \\ Luciana Maria Pedreira RAMALHO ${ }^{3}$
}

\begin{abstract}
${ }^{1}$ Center of Biophotonics, Dental School, UFBA - Federal University of Bahia, Salvador, BA, Brazil ${ }^{2}$ Oral Diagnosis Specialization Program, Dental School, Metropolitan Union of Culture and Education, Salvador, BA, Brazil ${ }^{3}$ Laboratory of Pathology, Dental School, Metropolitan Union of Culture and Education, Salvador, BA, Brazil
\end{abstract}

\begin{abstract}
Oral mucositis is a harmful side effect of radiotherapy (RT) on the head and neck region. There are encouraging reports on the beneficial aspects of the use of laser light on the treatment of oral mucositis. This paper reports the efficacy of laser phototherapy (LPT) on the treatment of oral mucositis in a patient undergoing RT after surgical removal of a squamous cell carcinoma with osseous invasion of the maxilla. Palatal and commissural lesions were treated with $\lambda 660 \mathrm{~nm}, 40 \mathrm{~mW}, \varnothing=4 \mathrm{~mm}^{2}$, in contact mode, $5 \times 2.4 \mathrm{~J} / \mathrm{cm}^{2} \mathrm{per}$ point, $14.4 \mathrm{~J} / \mathrm{cm}^{2}$ per session. For treating the lesion on the patient's nasal mucosa, LPT $\left(\varnothing=4 \mathrm{~mm}^{2}, \lambda 780 \mathrm{~nm}, 70 \mathrm{~mW}, 3 \times 2.1 \mathrm{~J} / \mathrm{cm}^{2}\right.$ per point, $6.3 \mathrm{~J} / \mathrm{cm}^{2}$ per session, contact mode) was used on the external area of the nose. A single dose $\left(2.4 \mathrm{~J} / \mathrm{cm}^{2}\right) \mathrm{with}$ the $\lambda 660 \mathrm{~nm}$ laser, as described before, was applied on the entrance of each nostril. LPT was used 3 times/week during 4 weeks. Treatment results indicate that the use of LPT on oral mucositis was effective and allowed the patient to carry on the RT without interruption. However, long-term and controlled clinical trials are necessary to establish both preventive and curative protocols using LPT.
\end{abstract}

Key Words: laser, phototherapy, cancer, radiotherapy, mucositis.

\section{INTRODUCTION}

Ionizing radiation causes damage to normal tissues located in the field of radiation. Oral mucositis may result from irradiation that induces the death of the basal cells of the mucosal epithelium, usually two weeks after the beginning of radiotherapy (RT) $(1,2)$.

Oral mucositis is an inflammatory response of the oral mucosa to the use of antineoplastic drugs or ionizing radiation that are used in treating head and neck cancer. Discomfort or severe oral pain may be caused by oral mucositis, as well as difficulties on drinking, eating, swallowing and speaking, which impair patient's quality of life $(1,3)$. It starts asymptomatic, later on, an erythema appears and it may be followed by erosion or ulceration of the oral mucosa. The ulcerations may be typically covered by a white fibrinous pseudomembrane $(4,5)$.

Histopathological evaluation of mucositis reveals mucosal thinning leading to the formation of a shallow ulcer thought to be caused by inflammation and depletion of the epithelial basal layer with subsequent denudation and bacterial infection (6).

The World Health Organization (WHO) Oral Toxicity Scale (OTS) is widely used for assessing the severity of scoring oral mucositis. This scale includes criteria such as the presence of erythema and ulceration, oral pain, and patient's ability to eat, in order to determine an overall score. The WHO OTS score 0 is defined as no abnormality found; score 1 is characterized by the presence of erythema requiring no treatment; score 2 is characterized by presence of pain requiring no analgesics, and difficulty in feeding; score 3 is characterized by ulceration, pain requiring analgesics, and feeding is impossible; and score 4 is characterized by necrosis, requiring total parenteral nutrition (5).

Several therapeutic approaches to treat oral

Correspondence: Profa. Dra. Luciana Maria Pedreira Ramalho, Laboratório de Patologia, Faculdade de Odontologia, UFBA, Avenida Araújo Pinho, 62, 9ª andar, Canela, 40110-150 Salvador, BA, Brasil. Tel/Fax: +55-71-3283-9026. e-mail: lucianaramalho@uol.com.br 
mucositis have been used, including basic oral care, oral rinses, analgesics, antibiotics, cryotherapy, local anesthetics, growth factors and cytokines, biologic mucosal protectants, and anti-inflammatory agents and others. To date, there is no single treatment capable of preventing or treating mucositis in an efficient way (7).

Recently, laser phototherapy (LPT) has been used both to prevent and to treat oral mucositis because of its ability to induce biological effects such as analgesia and modulation of the inflammatory process. The effect of LPT is due to its capacity to modulate diverse metabolic processes by biochemical and photophysical processes induced by the light that are beneficial for the cells $(8,9)$.

Several studies $(3,4,6,7,10,11)$ have suggested that the use of LPT seems to reduce the severity of mucositis, providing comfort and better quality of life. Zanin et al. (1) evaluated the effects of a 660-nm diode laser on the prevention and treatment of chemo- and radiotherapy-induced oral mucositis in patients with head and neck cancer. Their results showed that oral mucositis, pain, dysphonia and dysphagia were minimized with the use of LPT. This paper reports the efficacy of LPT in a patient suffering from oral mucositis induced by RT.

\section{CASE REPORT}

A 32-year-old Caucasian male patient was prescribed to carry on RT after undergoing surgery to remove an osseous-invasive squamous cell carcinoma of the maxilla (Fig. 1A). The RT protocol included a total dose of 6,000 cGy, within 30 fractions, over 6 weeks. In the second week of RT, he developed oral mucositis and severe oral pain. The patient was referred to the Laser Center of the Dental School of the Federal University of Bahia, Brazil. Clinical examination revealed widespread severely painful ulcerations both intraorally and extraorally (Fig. 2 A-E). The mucositis was scored as 3 , according to the WHO OTS criteria. In addition, the patient reported difficulty eating viscous/solid foods and breathing, as the nasal mucosa presented an extensive ulcerative lesion. He presented good oral health, as no periodontal problems or caries lesions were observed.

Oral hygiene guidance was provided and the sharp borders of teeth and restorations were removed with a fine bur and polished. LPT was performed using a GaAlAs diode laser (Twin-Flex ${ }^{\circledR}$; MMOptics, São Carlos, SP, Brazil) without interruption of RT. LPT $\left(\lambda 660 \mathrm{~nm}, \varnothing=4 \mathrm{~mm}^{2}, 40 \mathrm{~mW}\right.$, contact mode, $5 \times 2.4 \mathrm{~J} /$ $\mathrm{cm}^{2}$ per point, $14.4 \mathrm{~J} / \mathrm{cm}^{2}$ per session) was applied on the palatal and commissural lesions (Fig. 2A-C). The lesion on the nasal mucosa was too deep and impossible to reach with the laser handpiece (Fig. 2D-E). On this area, LPT $\left(\varnothing=4 \mathrm{~mm}^{2}, \lambda 780 \mathrm{~nm}, 70 \mathrm{~mW}, 3 \times 2.1 \mathrm{~J} / \mathrm{cm}^{2}\right.$ per point, $6.3 \mathrm{~J} / \mathrm{cm}^{2}$ per session) was used on contact mode on the external area of the nose corresponding to the inner lesion (Fig. 1B). In addition, a single dose $\left(\lambda 660 \mathrm{~nm}, \varnothing=4 \mathrm{~mm}^{2}, 40 \mathrm{~mW}\right.$, contact mode, $5 \times 2.4 \mathrm{~J} /$ $\mathrm{cm}^{2}$ per point, $14.4 \mathrm{~J} / \mathrm{cm}^{2}$ per session) was applied on the entrance of each nostril (Fig.1B). The LPT protocol comprise applications 3 times/week during 4 weeks.

At the beginning of treatment, the patient showed improvement of all symptoms. Following the first LPT session, a decrease in pain was reported. Further improvement was seen after the 4th irradiation session. At this time, the oral mucositis score was 2, and the patient was capable of eating solids normally. Ten LPT sessions were necessary to heal all lesions (Fig. 3AE), allowing the patient to carry on his routine daily activities.

\section{DISCUSSION}

To date, oral mucositis treatments are only palliative and include administration of topical antimicrobial agents, vitamins, growth factors, mouthwashes, cryotherapy and LPT (12). LPT is based on nonthermal effects of light on biological tissues, and its use in the prevention and treatment of mucositis induced by antineoplastic treatment has presented promising results, especially in clinical studies $(1,3,4,13)$. The effect of LPT is based on its ability to modulate several metabolic processes. Visible laser
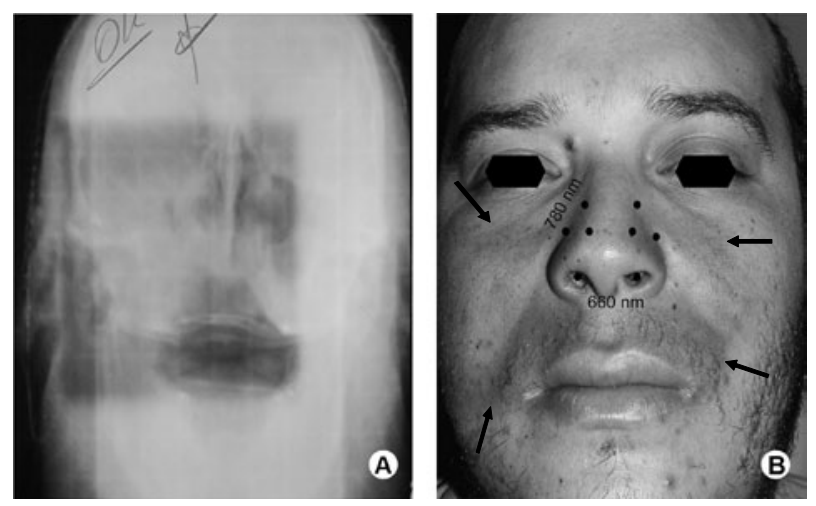

Figure 1. Radiotherapy Delimitation. A = Radiographic view of the area of the head treated with radiotherapy; $\mathrm{B}=$ Clinical photoerythema (arrows) and points of irradiation of the nasal mucosal lesion with $\lambda 780 \mathrm{~nm}$ and $\lambda 660 \mathrm{~nm}$ lasers. 
energy is absorbed by chromophores in the respiratory chain of the mitochondria, with an increase in ATP production resulting in increased cellular proliferation and protein synthesis, accelerating tissue repair (14).

Campos et al. (3), reported improvement in the quality of life of an oncological patient by LPT after 5 irradiation sessions when the mucositis score was 2 . In the present case, the patient showed a decrease in pain after the 1st LPT session and after 4 sessions the mucositis score was lowered from 3 to 2 . LPT caused an analgesic and anti-inflammatory effect, improving quality of life, reducing the need for analgesics and the medical costs for the patient (15).
Prophylactic use of LPT seems to be more effective than when it is used following the establishment of the disease, although the reason is not entirely clear (16). The patient of this case was referred to the Laser Center by the oncologist only after the oral mucositis lesions had been established. Therefore, LPT was used to minimize mucositis progression. LPT was proven beneficial, permitting that more patients can complete RT treatment with no major intercurrences. In the present case, the patient completed all RT sessions without interruption. It is important to highlight that, in addition to avoiding the antineoplasic treatment interruption, the pain relief also resulted in essential
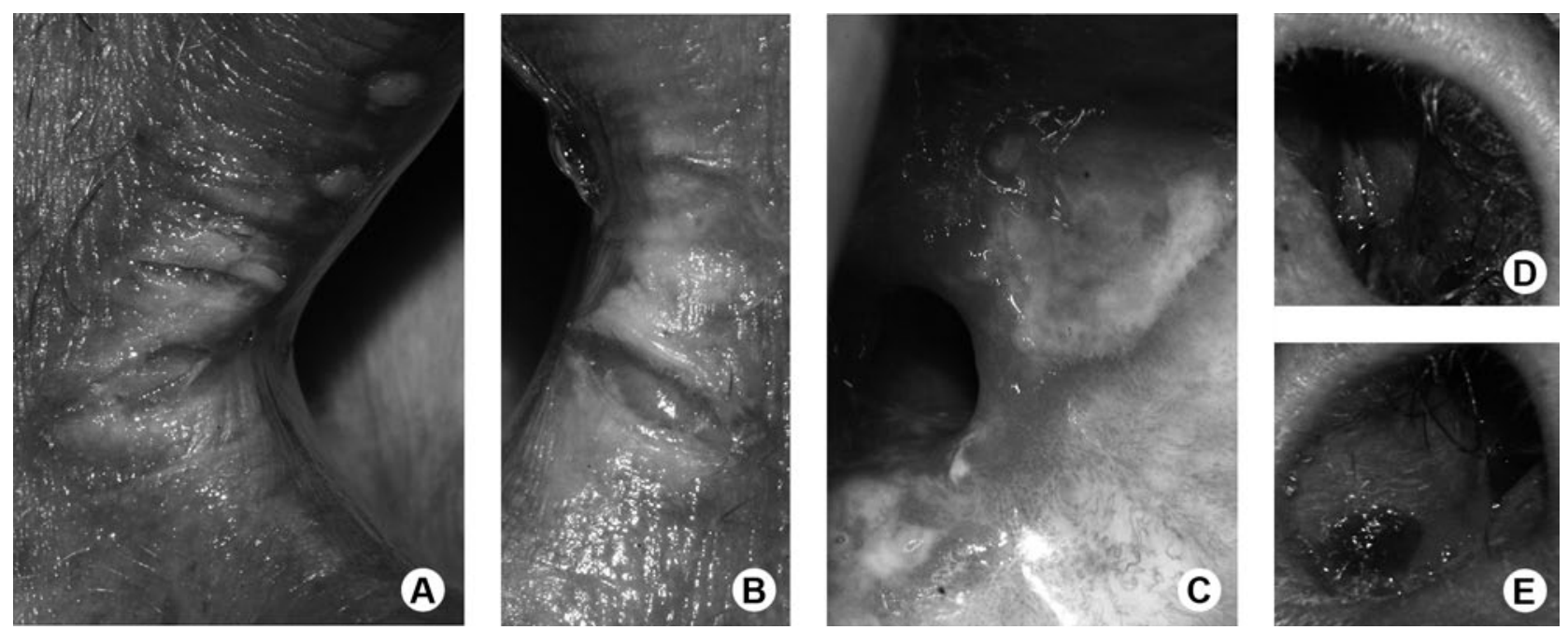

Figure 2. Clinical aspect before laser phototherapy. $\mathrm{A}-\mathrm{B}=$ Commissural lesions; $\mathrm{C}=$ Palatal lesion; $\mathrm{D}-\mathrm{E}=\mathrm{Nasal}$ mucosal lesions.
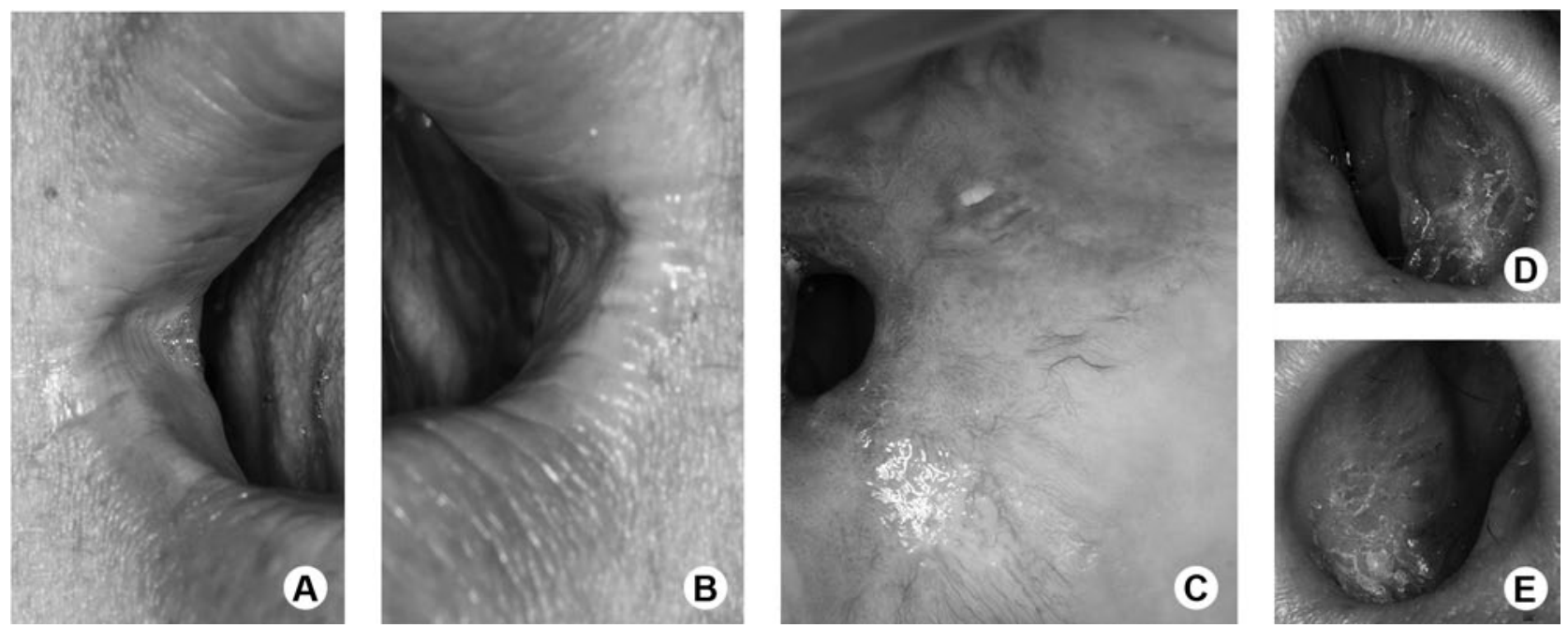

Figure 3. Clinical aspect before 10 laser phototherapy sessions. A-B $=$ Right and left comissura; $\mathrm{C}=$ Palate; $\mathrm{D}-\mathrm{E}=\mathrm{Right}$ and left nasal mucosa. 
improvements of basic oral functions, such as drinking, eating, swallowing and speech. The use of LPT avoids the need of parenteral feeding, as observed in cases of advanced mucositis (WHO OTS score 4), which demand hospital care. Accordingly, Zanin et al. (1) and Lopes et al. (17) reported that in their studies all patients under RT who received LPT completed the planned RT treatment, whereas patients not treated with LPT had to interrupt the RT because of decreased immunity caused by secondary asthenia and deglutition difficulties, which impacted their survival. Several protocols have been used for treating oral mucositis and the observed results sometimes differ $(1,3,4,13,16,17)$. It is necessary to standardize the protocols for prevention and treatment of this condition in order to make different studies comparable.

In the case described in this paper, LPT was proven a safe and effective method for treating oral mucositis as it resulted in pain relief, promoted healing of the lesions and reduced their severity, allowing the patient to eat normally and carry on his routine activities. The improvement in the patient's quality of life and the maintenance of the RT must be considered as important factors for the treatment outcome. Long-term and randomized controlled clinical trials are necessary to establish preventive and curative protocols using LPT.

\section{RESUMO}

A mucosite oral é um efeito colateral prejudicial da radioterapia na região de cabeça e pescoço. Existem estudos que evidenciam o efeito benéfico do uso da luz laser no tratamento da mucosite oral. O objetivo deste caso clínico foi o de avaliar a eficácia da fototerapia laser no tratamento da mucosite oral em um paciente sendo submetido a radioterapia, após a remoção cirúrgica de um carcinoma escamocelular, com invasão óssea da maxila. As lesões do palato e das comissuras labiais foram tratadas com $\lambda 660 \mathrm{~nm}$, $40 \mathrm{~mW}, \varnothing=4 \mathrm{~mm}^{2}$, em contato, $5 \times 2.4 \mathrm{~J} / \mathrm{cm}^{2}$ por ponto, $14.4 \mathrm{~J} /$ $\mathrm{cm}^{2}$ por sessão. Na lesão existente na mucosa nasal a fototerapia laser $\left(\varnothing=4 \mathrm{~mm}^{2}, \lambda 780 \mathrm{~nm}, 70 \mathrm{~mW}, 3 \times 2.1 \mathrm{~J} / \mathrm{cm}^{2}\right.$ por ponto, $6.3 \mathrm{~J} /$ $\mathrm{cm}^{2}$ por sessão, em contato) foi utilizada na área externa do nariz. Uma dose única $\left(2.4 \mathrm{~J} / \mathrm{cm}^{2}\right)$ com o laser $\lambda 660 \mathrm{~nm}$ e os parâmetros descritos anteriormente foi aplicado na entrada de cada narina. A fototerapia laser foi utilizada 3 vezes por semana, durante 4 semanas. Os resultados do tratamento são indicativos de que o uso da fototerapia laser em mucosite oral foi efetiva e permitiu ao paciente continuar o tratamento radioterápico sem interrupções. Entretanto, estudos clínicos controlados são necessários para se estabelecer os protocolos, para tratamento e prevenção da mucosite oral, utilizando fototerapia laser.

\section{REFERENCES}

1. Zanin T, Zanin F, Carvalhosa AA, Castro PHS, Pacheco MT, Zanin ICJ, et al.. Use of 660-nm diode laser in prevention and treatment of human oral mucositis induced by radiotherapy and chemotherapy. Photomed Laser Surg 2010;28:233-237.

2. Scully C, Epstein J, Sonis S. Oral mucositis: a challenging complication of radiotherapy, chemotherapy, and management of mucositis. Head and Neck 2004;26:77-84.

3. Campos L, Simões A, Sá PHRN, Eduardo CP. Improvement in quality of life of an oncological patient by laser phototherapy. Photomed Laser Surg 2009;27:371-374.

4. Khouri VY, Stracieri ABPL, Rodrigues MA, Moraes DA, Pieroni F, Simões BP, et al.. Use of therapeutic laser for prevention and treatment of oral mucositis. Braz Dent J 2009;20:215-220.

5. Brennan MT, Woo SB, Lockhart PB. Dental treatment planning and management in the patient who has cancer. Dent Clin North Am 2008;52:19-37.

6. Bensadoun RJ. Low level laser therapy (LLLT): A new paradigm in the management of cancer therapy-induced mucositis? Indian J Med Res 2006;124:375-378.

7. França CM, França CM, Núñez SC, Prates RA, Noborikawa E, Faria MR, et al.. Low-intensity red laser on the prevention and treatment of induced-oral mucositis in hamsters. Photochem Photobiol 2009;94:25-31.

8. Karu TI, Kolyakov SF. Exact Action Spectra for Cellular Responses Relevant to Phototherapy. Photomed Laser Surg 2005;23:355-361.

9. Pinheiro ALB, Brugnera Júnior A, Zanin FAA. Aplicação do Laser na Odontologia. São Paulo: Santos; 2010.

10. Lopes NNFL, Plapler H, Chavantes MC, Lalla RV, Yoshimura EM, Alves MTS. Cyclooxygenase-2 and vascular endothelial growth factor expression in 5-fluorouracil-induced oral mucositis in hamsters: evaluation of two low-intensity laser protocols. Support Care Cancer 2009;17:1409-1415.

11. Lima AG, Antequera R, Peres MP, Snitcosky IM, Federico MH, Villar RC. Efficacy of low-level laser therapy and aluminum hydroxide in patients with chemotherapy and radiotherapyinduced oral mucositis. Braz Dent J 2010;21:186-192.

12. Wolfgang J, Köstler MH, Hejna M, Wenzel C, Zielinski CC. Oral mucositis complicating chemotherapy and/or radiotherapy: Options for prevention and treatment. CA Cancer J Clin 2001;51:290-315.

13. Maiya GA, Sagar MS, Fernandes D. Effect of low level heliumneon (He-Ne) laser therapy in the prevention and treatment of radiation induced mucositis in head and neck cancer patients. Indian J Med Res 2006;124:399-402.

14. Karu, TI. Molecular mechanism of the therapeutic effect of lowintensity laser radiation. Lasers Life Sci 1988;2:53-74.

15. Bjordal JM, Johnson MI, Iversen V, Aimbire F, Lopes-Martins RAB. Low-Level Laser Therapy in acute pain: A systematic review of possible mechanisms of action and clinical effects in randomized placebo-controlled trials. Photomed Laser Surg 2006;24:158-168.

16. Arora H, Pai KM, Maiya A, Vidyasagar MS, Rajeev A. Efficacy of He-Ne Laser in the prevention and tretament of radiotherapyinduced oral cancer patient. Oral Surg Oral Med Oral Pathol Oral Radiol Endod 2008;105:180-186.

17. Lopes C, Mas JRI, Zângaro RA. Low level laser therapy in the prevention of radiotherapy-induced xerostomia and oral mucositis. Radiol Bras 2006;39:131-136. 